\title{
INTERPRETASI MAHKAMAH KONSTITUSI TERHADAP PENGUJIAN PERATURAN PEMERINTAH PENGGANTI UNDANG-UNDANG
}

\author{
Anwar Hafidzi \\ Universitas Islam Negeri Antasari, Banjarmasin \\ Jalan Ahmad Yani, Km. 4.5 Banjarmasin, Kalimantan Selatan, Indonesia \\ E-mail: anwar.hafidzi@uin-antasari.ac.id \\ Panji Sugesti \\ Universitas Islam Negeri Antasari, Banjarmasin \\ Jalan Ahmad Yani, Km. 4.5 Banjarmasin, Kalimantan Selatan, Indonesia \\ E-mail: panji.sugesti@uin-antasari.ac.id
}

\begin{abstract}
The Constitutional Court of the Republic of Indonesia has 4 (four) authorities and one obligation, as for those authorities, namely: (1) The Constitutional Court has the authority to adjudicate at the first and last level whose decisions are final to test the Law against the Constitution, (2) decide authority disputes of State Institutions whose authority is granted by the Constitution, (3) decide upon the dissolution of political parties, (4) and decide upon disputes about the results of general elections. The obligations, namely the Constitutional Court is obliged to give a decision on the opinion of the House of Representatives regarding the alleged violation by the President and / or Vice President. Beyond the specified authority, the Constitutional Court has increased its authority to test the Substitute Government Regulations. The research method used in this study is a type of normative legal research that is a literature study or documentary, by examining theories, concepts and legal principles. The results of this study found that there is indeed no rule that gives the Constitutional Court authority to test regulation in lie of law, but the Constitutional Court has the consideration that the legal norms contained in the Perppu are the same as the Law. The results of this study are that the interpretation used by constitutional justices to test Perppu is a teleological and sociological interpretation.
\end{abstract}

Keywords: Interpretation; Test; PERPPU; Constitutional Court.

\begin{abstract}
Abstrak: Mahkamah Konstitusi Republik Indonesia memiliki 4 (empat) kewenangan dan satu kewajiban, adapun kewenangan tersebut yaitu: (1) Mahkamah Konstitusi berwenang mengadili pada tingkat pertama dan terakhir yang putusannya bersifat final untuk menguji Undang-Undang terhadap Undang-Undang Dasar, (2) memutus sengketa kewenangan Lembaga Negara yang kewenangannya diberikan oleh Undang-Undang Dasar, (3) memutus pembubaran partai politik, (4) dan memutus perselisihan tentang hasil pemilihan umum. Adapun kewajibannya yaitu Mahkamah Konstitusi wajib memberikan putusan atas pendapat Dewan Perwakilan Rakyat mengenai dugaan pelanggaran oleh Presiden dan/atau Wakil Presiden. Diluar kewenangan yang telah ditentukan tersebut Mahkamah Konstitusi telah menambah kewenangannya untuk menguji Peraturan Pemerintah Pengganti UndangUndang. Metode penelitian yang digunakan dalam penelitian ini adalah jenis penelitian hukum normatif yang bersifat studi pustaka atau dokumenter, dengan cara menelaah teori-teori, konsep-konsep serta asas-asas hukum. Hasil penelitian ini menemukan bahwa memang secara tegas tidak ada aturan yang memberikan kewenangan Mahkamah Konstitusi untuk menguji peraturan pemerintah pengganti Undang-Undang, akan tetapi Mahkamah Konstitusi memilikipertimbangan bahwa norma hukum yang terkandung dalam Perppu kekuatannya sama dengan Undang-Undang. Maka, temuan kedua adalah bahwa penafsiran yang digunakan oleh hakim konstitusi untuk menguji Perppu adalah interpretasi teleologis dan sosiologis.
\end{abstract}

Kata Kunci: Interpretasi; Uji Materi; PERPPU; Mahkamah Konstitusi. 
AL-IMARAH: Jurnal Pemerintahan dan Politik Islam

Vol. 4, No. 2, 2019

\section{Pendahuluan}

Mahkamah Konstitusi Republik Indonesia adalah salah satu pelaku kekuasaan kehakiman, selain Mahkamah Agung dan badan-badan peradilan di bawahnya. Sebagai lembaga peradilan, Mahkamah Konstitusi memiliki peran strategis dalam menjaga dan menjamin pelaksanaan prinsip dan norma yang terkandung dalam konstitusi sebagai norma tertinggi dalam menerapkan kehidupan bernegara. (the supreme law of the land). Karena itu, Mahkamah Konstitusi disebut juga sebagai the guardian of the constitution. ${ }^{1}$

\section{Mahkamah Konstitusi Republik} Indonesia memiliki 4 (empat) otoritas dan satu kewajiban, adapun otoritas-otoritas tersebut, yaitu: (1) Mahkamah Konstitusi berwenang untuk mengadili pada tingkat pertama dan terakhir yang keputusannya final untuk menguji UU. bertentangan dengan Konstitusi, (2) memutuskan sengketa kewenangan Lembaga Negara yang kewenangannya diberikan oleh Konstitusi, (3) memutuskan pembubaran partai politik, (4) dan memutuskan sengketa tentang hasil pemilihan umum. Kewajiban tersebut, yaitu pengadilan konstitusi harus memberikan keputusan atas

\footnotetext{
1 Maruarar Siahaan and Indonesia, Hukum acara Mahkamah Konstitusi Republik Indonesia (Jakarta: Sinar Grafika, 2011), 7. Bandingkan dalam Luthfi Widagdo Eddyono, "Penyelesaian Sengketa Kewenangan Lembaga Negara Oleh Mahkamah Konstitusi," Jurnal Konstitusi 7, no. 3 (2010): 1-48; Nur Rohim, "Kontroversi Pembentukan Perppu Nomor 1 Tahun 2013 Tentang Mahkamah Konstitusi Dalam Ranah Kegentingan Yang Memaksa," Jurnal Cita Hukum 2, no. 1 (2014).

pendapat DPR tentang dugaan pelanggaran oleh Presiden dan / atau Wakil Presiden sesuai dengan Konstitusi.

Kewenangan Mahkamah Konstitusi untuk memutuskan perselisihan di antara lembaga-lembaga negara lainnya tidak berarti bahwa Mahkamah Konstitusi memiliki posisi yang lebih tinggi secara hierarkis, yang berfungsi sebagai upaya untuk memeriksa dan menyeimbangkan untuk membentuk konstitusi.

Dari sini dapat dipahami posisi Mahkamah Konstitusi adalah salah satu lembaga negara yang melakukan kekuasaan kehakiman secara independen untuk melakukan keadilan untuk menegakkan konstitusi. $^{2}$

\section{Undang-Undang Nomor 12 Tahun}

2011 tentang Pembentukan Peraturan Perundang-undangan menjelaskan bahwa Peraturan Perundangan-undangan adalah peraturan tertulis yang memuat norma hukum yang mengikat secara umum dan dibentuk atau ditetapkan oleh lembaga negara atau pejabat yang berwenang melalui prosedur yang ditetapkan dalam Peraturan Perundangundangan.

Hirarki peraturan perundangundangan berdasarkan sebagaimana termuat

${ }^{2}$ Abdul Latief, Fungsi Mahkamah Konstitusi dalam upaya mewujudkan negara hukum demokrasi (Yogyakarta: Kreasi Total Media, 2007), 53. Ajie Ramdan, "Kewenangan Penuntut Umum Mengajukan Peninjauan Kembali Pasca Putusan Mahkamah Konstitusi No. 33/PUU-XIV/2016," Jurnal Ilmiah Kebijakan Hukum 11, no. 2 (July 25, 2017):h. 181192. 
dalam Undang-Undang Nomor 12 Tahun 2011 pasal 7 ayat 1 Tentang Pembentukan Peraturan Perundang-undangan sebagai berikut:

a) Udang-Undang Dasar Negara Republik Indonesia Tahun 1945;

b) Ketetapan MPR;

c) Undang-Undang/Peraturan Pemerintah Pengganti Undang-Undang;

d) Peraturan Pemerintah;

e) Peraturan Presiden;

f) Peraturan Daerah Provinsi;

g) Peraturan Daerah Kabupaten/Kota

Sistem pengujian peraturan perundang undangan di Indonesia mengisyaratkan, bahwa suatu peraturan perundang-undangan dapat digugat atau dimohonkan pengujiannya karena:

1) Pembentukan Undang-Undang tidak memenuhi ketentuan berdasarkan Undang-Undang Dasar 1945;

2) Materi muatan dalam ayat, pasal, dan/atau bagian Undang-Undang bertentangan dengan Undang-Undang Dasar 1945; atau

3) Materi muatan dalam ayat, pasal, dan/atau bagian peraturan perundangundangan dibawah Undang-Undang bertentangan dengan Undang-Undang.

Perkembangan ketatanegaraan kita dewasa kini, pengujian konstitusionalitas Undang-Undang yang merupakan satusatunya mekanisme penghapusan atau pembatalan Undang-Undang kini dianggap amat penting dan mendesak untuk dilakukan. Hal ini disebabkan karena atas berlakunya suatu Undang-Undang, maka bisa saja mengurangi atau menghilangkan hak dan/atau kewenangan konstitusional warga negara, atau bahkan atas berlakunya UndangUndang tersebut dapat menciderai prinsip demokrasi negara Indonesia. "The judiciary is conservative in its procedures, but its impact on society can be radical. That impact depends on a variety of influences ". 3

Untuk itu Undang-undang yang dianggap bertentangan dengan konstitusi sepatutnya harus segera diuji sejak pemberlakuannya. Hal ini pun berlaku terhadap disahkannya suatu Peraturan Pemerintah Pengganti Undang-undang (PERPPU). Perppu yang meskipun masa berlakunya hanya sampai persidangan pembahasan di DPR (jika tidak disetujui menjadi Undang-undang), tetapi tetap saja dalam kurun waktu yang sebentar itu jika di tidak sejalan dengan maksut konstitusi dan merugikan hak-hak konstitusional warga negara yang di jamin oleh konstitusi, bagaimanapun Perppu itu sendiri memang merupakan undang-undang yang dibentuk dengan syarat dalam keadaan darurat yang menurut istilah pasal 22 ayat (1) UUD 1945

3 Theodore J. Lowi et al., American Government: Power and Purpose (W.W. Norton, 2015), 345. Rohim, "Kontroversi Pembentukan Perppu Nomor 1 Tahun 2013 Tentang Mahkamah Konstitusi Dalam Ranah Kegentingan Yang Memaksa." 
disebutkan "Dalam hal ihwal kegentingan yang memaksa".

Mahkamah Konstitusi nyatanya telah beberapa kali melakukan pengujian PERPPU terhadap UUD. Putusan Mahkamah Konstitusi Nomor 138/PUU-VII/2009, pengujian Perppu Nomor 4 Tahun 2009 tanggal 8 Februari 2010 adalah sejarah baru dalam praktik ketatanegaraan kita, karena ternyata Mahkamah Konstitusi memutuskan bahwa dirinya berwenang dalam menguji Perppu tersebut. Meskipun amar putusannya menyatakan permohonan tidak dapat diterima (niet ontvankelijk verklaard) karena alasan para pemohon tidak mempunyai kedudukan hukum (legal standing) untuk mengajukan permohonan a quo, tetapi setidaknya Mahkamah Konstitusi telah menyatakan keberwenangannya untuk memeriksa, mengadili dan memutus permohonan pengujian Perppu terhadap UUD.

Karena pada dasarnya permohonan tidak akan masuk pada pemeriksaan pokok permohonan apabila Mahkamah Konstitusi berpendapat tidak mempunyai kewenangan/kompetensi untuk menguji Perppu terhadap Undang-Undang Dasar 1945. Hal ini menimbulkan polemik apakah benar Mahkamah Konstitusi berwenang dalam melakukan pengujian Perppu bukankah wewenang Mahkamah Konstitusi sudah jelas di atur dalam pasal 24C UUD 1945 sudah jelas dan tegas menyebutkan objectum litis (objek perkara) dalam perkara pengujian Undang-Undang di Mahkamah Konstitusi adalah Undang-Undang, dan tidak ada menyebutkan Perppu. ${ }^{4}$ Mekanisme pengujian (review) terhadap Perppu sendiri sudah diatur dalam Pasal 22 ayat (2) dan (3) UUD RI 1945, yaitu menjadi kewenangan DPR.

\section{Pembahasan}

Kewenangan untuk menguji validitas supremasi hukum di Indonesia dipegang oleh Mahkamah Agung dan Mahkamah Konstitusi. ${ }^{5}$ Menguji normanorma aturan hukum sebagai kekuatan yudisial didefinisikan sebagai kekuatan independen, terlepas dari pengaruh kekuasaan pemerintah atau kekuatan lain. Kewenangan untuk menguji validitas supremasi hukum di Indonesia diajukan ke pengadilan, yaitu Mahkamah Konstitusi dan Mahkamah Agung. Bukan ke lembaga lain, meski legislatif. Otoritas penguji ini terletak pada pembagian kekuasaan negara untuk memberi makna pada tindakan mengawasi kebijakan yang dibuat sesuai dengan prinsip negara.

Sebelum dilakukannya amandemen terhadap UUD 1945 berdasarkan Tap MPR

4 Ramdan, "Kewenangan Penuntut Umum Mengajukan Peninjauan Kembali Pasca Putusan Mahkamah Konstitusi No. 33/PUU-XIV/2016,'’h. 182.

${ }^{5}$ Kristian, Kewenangan Mahkamah Konstitusi Terhadap Constitutional Complaint, Pt. Animage. (Jakarta, 2019)., 4. Abdul Ghoffar, "Mewujudkan Mahkamah Konstitusi Sebagai Peradilan Yang Akuntabel Dan Terpercaya," Pandecta: Research Law Journal 13, no. 2 (December 31, 2018):h. 76-88. 
No. III/MPR/2000 lembaga yang memiliki wewenang menguji UU terhadap UUD ini diberikan kepada MPR, tepatnya diatur dalam Pasal 5 ayat (1) Tap MPR No. III/MPR/2000 namun dalam prakteknya setelah Ketetapan ini keluar wewenang menguji UU ini tidak pernah digunakan oleh MPR.

Lahirnya Tap MPR dan wewenang menguji UU oleh lembaga MPR ini didasarkan pada pandangan bahwa MPR adalah pelaksana kedaulatan rakyat (Pasal 1 ayat (2) UUD 1945 sebelum amandemen) yang dapat dianalogikan dengan posisi parlemen di Negara Inggris. Pandangan yang demikian ini pada dasarnya tidak dapat diterima karena sistem ketatanegaraan Inggris berbeda dengan sistem ketatanegaraan yang berlaku di Indonesia. Dalam ketatanegaraan Inggis dikenal supremasi parlemen, sedangkan di Indonesia menganut prinsip supremasi Udang-Undang Dasar (dalam hal ini UUD 1945). Di Inggris tidak terdapat atau dikenal suatu konstitusi sebagai "the Supreme law" sehingga tidak mungkin menguji konstitusionalitas "parliamentary act"'.

Negara-negara yang berhasil untuk mewujudkan cita-cita Negara hukum yang demokratis dan tegaknya paham

6 Ibnu Sina Chandranegara, "Perbandingan Fungsi Dan Kedudukan Mahkamah Konstitusi Dan Lembaga Sejenisnya Di Tiga Negara (Indonesia, Austria Dan Perancis)," Socio Justisia 1, no. 1 (March 17, 2018), accessed April 27, 2019, https://jurnal.umj.ac.id/index.php/socio/article/view/2 534. konstitusionalisme, salah satunya sangat ditentukan oleh keberhasilan badan peradilan dalam menjalankan fungsinya atau tugasnya, hal itu dilakukan oleh Mahkamah tersendiri yang bernama Mahkamah Konstitusi atau badan dengan nama lain yang diberi tugas atau fungsi demikian, karena bagaimana pun, suatu Undang-Undang berdasarkan proses pembentukanya adalah sebuah produk politik. Dalam konteks bahwa suatu UndangUndang adalah produk politik, maka fungsi judicial review Mahkamah Konstitusi bukan saja berperan penting dalam menjaga agar produk politik tidak bertentangan dengan konstitusi atau Undang-undang.

Pengujian satu aturan hukum dengan aturan hukum lainnya perlu dilakukan untuk menjaga kesatuan sistem hukum di negara tersebut. terutama jika aturan hukum mengesampingkan aturan hukum yang lebih penting dan tingkat yang lebih tinggi. Perbedaan dan kontradiksi antara aturan hukum dalam undang-undang harus diselesaikan dan diberhentikan oleh lembaga peradilan yang memiliki wewenang untuk menentukan apa yang merupakan hukum positif di suatu negara.

Pengujian konstitusional materi ini memiliki dasar yang kuat di negara berdasarkan UUD 1945 Republik Indonesia sebagai kumpulan aturan dasar yang dianggap Agung dibandingkan dengan aturan lain. Secara umum, pemeriksaan Konstitusi, kantor peradilan dapat membatasi atau 
mengontrol perilaku posisi Legislatif dan Eksekutif berdasarkan konstitusi. Hal ini dilakukan dalam rangka menjamin hak asasi manusia dan kebebasan warga negara dan dalam mencegah tindakan sewenang-wenang pihak yang tidak bertanggungjawab. ${ }^{7}$

Istilah pengujian peraturan perundang-undangan dapat dibagi berdasarkan subjek yang melakukan pengujian, objek peraturan yang diuji, dan waktu pengujian. Dalam praktek, dikenal adanya tiga macam norma hukum yang dapat diuji atau bisa disebut Norm Control Mechanism. Ketiganya sama-sama merupakan bentuk norma hukum, yaitu keputusan normatif yang berisi dan bersifat pengaturan (regeling), keputusan normatif yang berisi dan bersifat administratif (bechecking), dan keputusan normatif yang berisi dan bersifat penghakiman (Judgement) yang disebut Vonis. Ketiga bentuk norma hukum tersebut sama-sama dapat diuji kebenaranya melalui mekanisme non justicial, jika pengujian itu dilakukan oleh lembaga peradilan, maka proses pengujianya itu disebut sebagai judicial review atau pengujian oleh lembaga yudisial atau pengadilan. $^{8}$

${ }^{7}$ Titik Triwulan Tutik, Konstruksi hukum tata negara Indonesia pasca-amandemen UUD 1945 (Jakarta: Kencana, 2010), 25.

${ }^{8}$ Jimly Asshiddiqie, Hukum Acara Pengujian Undang-Undang, [Cet. 2.]. (Jakarta: Sekretariat Jenderal dan Kepaniteraan Mahkamah Konstitusi RI, 2006), 1-2. 102
Dilihat dari segi subjek yang melakukan pengujian, pengujian dapat dilakukan oleh hakim (toetsingsrecht van de rechter atau judicial review), pengujian oleh lembaga legislatif (legislative review), maupun pengujian oleh lembaga eksekutif (executive review). Dalam praktiknya peraturan perundang-undangan di Indonesia telah mengatur ketiga pengujian tersebut. Pengujian oleh hakim (toetsingsrecht van de rechter atau judicial review) diatur baik sebelum maupun sesudah perubahan UUD 1945. Pengaturan mengenai pengujian peraturan perundang-undangan pada masa berlakunya UUD 1945, pertama kali diatur dalam UU Nomor 14 Tahun 1970 tentang Ketentuan-Ketentuan Pokok Kekuasaan Kehakiman, yang mengatur pengujian terhadap peraturan perundang-undangan di bawah undang-undang terhadap undangundang merupakan kewenangan Mahkamah Agung.

Setelah perubahan UUD 1945, kewenangan pengujian peraturan perundangundangan di bawah undang-undang terhadap Undang-Undang tetap merupakan kewenangan Mahkamah Agung, sedangkan pengujian Undang-Undang terhadap UndangUndang Dasar merupakan kewenangan Mahkamah Konstitusi. Pengujian undangundang oleh lembaga legislatif (legislative review) dilakukan dalam kapasitas sebagai lembaga yang membentuk dan membahas serta menyetujui Undang-Undang (bersama- 
Anwar Hafihi dan Panji Sugesti:

Interpretasi Mahkamah Konstitusi Terhadap Pengujian Peraturan Pemerintah Pengganti Undang-Undang

sama Presiden). Sebelum perubahan UUD pembatalan Perda ditetapkan dalam 1945, pengujian undang-undang terhadap UUD berada pada MPR berdasarkan Peraturan Presiden. ${ }^{9}$

Ketetapan MPR RI Nomor III/MPR/2000

Tentang Sumber Hukum Dan Tata Urutan Peraturan Perundang Undangan.

Sebagaimana pengujian oleh lembaga legislatif (legislative review) yang dilakukan dalam kapasitas sebagai lembaga yang membentuk dan membahas serta menyetujui undang-undang (bersama dengan Presiden), pengujian oleh lembaga eksekutif (executive review) dilakukan terhadap peraturan perundang-undangan yang dibentuk oleh lembaga eksekutif. Salah satu contoh pengujian oleh lembaga eksekutif (executive review) adalah dalam pengujian Peraturan Daerah (Perda). Untuk melaksanakan pemerintahan daerah, penyelenggara pemerintahan daerah (pemerintah daerah dan DPRD) membentuk Perda, yang akan ditetapkan oleh Kepala Daerah setelah mendapat persetujuan bersama DPRD. Berdasarkan Pasal 136 UU No 32/2004, Perda dilarang bertentangan dengan kepentingan umum dan/atau peraturan perundang-undangan yang lebih tinggi Dan berdasarkan Pasal 145 UU 32/2004, Pemerintah dapat membatalkan Perda yang bertentangan dengan kepentingan umum dan/atau peraturan perundangundangan yang lebih tinggi, Keputusan

\footnotetext{
${ }^{9}$ Ibid, hlm. 82.

${ }^{10}$ Ibid, hlm. 83.

11 Jimly Asshiddiqie, Perihal UndangUndang Di Indonesia (Jakarta: Mahkamah Konstitusi RI Sekretariat Jenderal dan Kenpaniteraan, 2006), 133.
} 


\section{Interpretasi Hakim Konstitusi}

Sudikno Mertokusumo dan A. Pitlo mengidentifikasikan beberapa metode interpretasi yang lazimnya digunakan oleh hakim pengadilan sebagai berikut:

\section{a. Interpretasi gramatikal}

Interpretasi gramatikal atau interpretasi menurut bahasa ini memberikan penekanan pada pentingnya kedudukan bahasa dalam rangka memberikan makna terhadap sesuatu objek. Sukar dibayangkan, hukum ada tanpa adanya bahasa. Positief recht bestaat dus allen maar dankzij het feit dat de mens een taal heft hukum positif itu ada hanya karena kenyataan bahwa manusia memiliki bahasa.

Bahasa merupakan salah satu faktor kunci untuk bagaimana kita dapat mengetahui sengketa hukum (legal disputes) yang sebenarnya dikonstruksi oleh hakim (pengadilan). Metode interpretasi gramatikal yang disebut juga metode penafsiran objektif merupakan cara penafsiran atau penjelasan yang paling sederhana untuk mengetahui makna ketentuan undang-undang dengan menguraikannya menurut bahasa, susunan kata atau bunyinya. Dari sini arti atau makna ketentuan undangundang dijelaskan menurut bahasa sehari-hari yang umum tetapi dengan bahasa yang logis.

\section{b. Interpretasi teleologis atau sosiologis}

Interpretasi teleologis atau sosiologis adalah apabila makna undang-undang ditetapkan berdasarkan tujuan kemasyarakatan. Di siniperaturan perundang-undangan disesuaikan dengan hubungan dan situasi sosial yang baru. Jadi peraturan hukum yang lama disesuaikan dengan keadaan baru atau dengan kata lain peraturan yang lama dibuat aktual. ${ }^{12}$

\section{c. Interpretasi sistematis atau logis}

Terjadinya suatu undang-undang selalu berkaitan dengan peraturan perundang-undangan lain, dan tidak ada undang-undang yang berdiri sendiri lepas sama sekali dari keseluruhan sistem perundang-undangan. Setiap undang-undang merupakan bagian dari keseluruhan sistem perundangundangan.

Menafsirkan undang-undang sebagai bagian dari keseluruhan sistem perundang-undangan dengan jalan menghubungkannya dengan undangundang lain disebut dengan interpretasi sistematis atau interpretasi logis.

\section{d. Interpretasi historis}

Makna ketentuan dalam suatu peraturan perundang-undangan dapat juga ditafsirkan dengan cara meneliti sejarah pembentukan peraturan itu sendiri. Penafsiran ini dikenal dengan

\footnotetext{
${ }^{12}$ Ibid., hlm. 72.
} 
Anwar Hafihi dan Panji Sugesti: Interpretasi Mahkamah Konstitusi Terhadap Pengujian Peraturan Pemerintah Pengganti Undang-Undang

istilah interpretasi historis. Dengan penafsiran menurut sejarah undangundang hendak dicari maksud ketentuan undang-undang seperti yang dilihat atau dikehendaki oleh pembentuk undangundang pada waktu pembentukannya. Pikiran yang mendasari metode interpretasi ini ialah bahwa undangundang adalah kehendak pembentuk undang-undang yang tercantum dalam teks undang-undang. Interpretasi menurut sejarah undang-undang ini di sebut juga interpretasi subjektif, karena penafsir menempatkan diri pada pandangan subjektif pembentuk undangundang, sebagai lawan interpretasi menurut bahasa yang disebut metode objektif. $^{13}$

Penafsiran historis ini disebut juga dengan penafsiran orisinal, yaitu bentuk atau metode penafsiran konstitusi yang didasarkan pada sejarah konstitusi atau undang-undang itu di bahas, di bentuk, di adopsi atau diratifikasi oleh pembentuknya. Pada umumnya metode penafsiran ini menggunakan pendekatan original intent terhadap norma-norma hukum konstitusi.

\section{e. Interpretasi komparatif atau perbandingan \\ Interpretasi komparatif atau perbandingan merupakan metode penafsiran yang dilakukan dengan jalan}

memperbandingkan antara beberapa aturan hukum. Tujuan hakim memperbandingkan adalah dimaksudkan untuk mencari kejelasan mengenai makna dari suatu ketentuan undangundang.

Interpretasi perbandingan dapat dilakukan dengan jalan membandingkan penerapan asas-asas hukumnya (reehtsbegi nsel en) dalam peraturan perundang-undangan yang lain dan/atau aturan hukumnya (rechtsregel), disamping perbandingan tentang latar belakang atau sejarah pembentukan hukumnya.

\section{f. Interpretasi futuristis}

Interpretasi futuristis atau metode penemuan hukum yang bersifat antisipasi adalah penjelasan ketentuan undang-undang yang belum mempunyai kekuatan hukum. Dengan demikian, interpretasi ini lebih bersifat ius constituendum (hukum atau undangundang yang dicitakan) dari pada ius constitutum (hukum atau undang-undang yang berlaku pada saat sekarang).

Hukum positif tampaknya belum dapat menentukan pola metode hukum dengan jelas. Dari sekian banyak jenis metode interpretasi konstitusional yang ada atau berkembang dalam praktik peradilan di Mahkamah Konstitusi (baik yang digunakan oleh pemohon, terdakwa, pihak terkait, saksi, ahli, atau

${ }^{13}$ Ibid., hlm. 73. 
hakim konstitusi ), tidak ada metode penafsiran konstitusi tertentu yang harus dipilih dan digunakan oleh hakim. Dalam praktik peradilan, satu metode untuk menafsirkan konstitusi dapat digunakan oleh hakim bersama dengan metode lain untuk menafsirkan konstitusi. Tidak ada persyaratan bagi hakim untuk hanya memilih dan menggunakan satu metode interpretasi konstitusional. ${ }^{14}$

Pemanfaatan metode-metode interpretasi yang beragam dalam praktik peradilan, dan tidak adanya tatanan yang hierarkis di antara metode-metode itu menurut JA.Pontier mengimplikasikan kebebasan hakim yang luas untuk mengambil keputusan.

Para hakim di lingkungan Mahkamah Konstitusi Indonesia seyogyanya juga memahami isyarat bahwa kebebasan yang teramat besar dapat mengakibatkan ketidakpastian hukum dan membuka kemungkinan subjektifitas hakim yang kaku. Ijtihad para hakim konstitusi dalam rangka Rechtsvinding hingga sampai pada putusannya merupakan bagian dari amanat Undang-Undang Kekuasaan Kehakiman, bahwa sebagai peradilan negara, Mahkamah Konstitusi harus menerapkan dan menegakkan hukum dan keadilan berdasarkan Pancasila, di samping juga wajib menggali, mengikuti, dan memahami nilai-nilai hukum dan rasa keadilan yang hidup di dalam masyarakatnya. ${ }^{15}$

\section{Kewenangan Pengujian}

\section{Konstitusiolitas}

Perppu yang dilakukan oleh Mahkamah Konstitusi, tidak ada aturan yang secara eksplisit memberikan kewenangan kepada Mahkamah Konstitusi untuk melakukan judicial review Perppu. Namun demikian kekosongan hukum terkait kewenangan untuk melakukan judicial review Perppu sangat berpotensi terdapatnya Perppu yang secara materil bertentangan dengan UUD 1945, atau bahkan Perppu yang akan melanggar hak-hak konstitusional warga negara, namun tidak ada lembaga yang dapat mengujinya secara yudisial.

$$
\text { Dalam rangka menjaga }
$$

konstitusi, dan hak-hak warga negara, tidak seharusnya terdapat peraturan perundang-undangan yang tidak dapat diuji secara yudisial. Karena peraturan perundang-undangan adalah produk pemerintah selaku pembuat undangundang, dan syarat dengan muatan politik. Sehingga ada kemungkinan peraturan perundang-undangan yang dibuat oleh pemerintah tersebut melanggar konstitusi dan merugikan hak-hak rakyat.

\footnotetext{
${ }^{14}$ Ibid., hlm. 74-75.
}

${ }^{15}$ Ibid., hlm. 80 . 
Anwar Hafihi dan Panji Sugesti: Interpretasi Mahkamah Konstitusi Terhadap Pengujian Peraturan Pemerintah Pengganti Undang-Undang

Tentu sepatutnya segala peraturan perundang-undangan harus tetap diawasi oleh kekuasaan di luar kekuasaan pembentuk peraturan perundang-undangan. Tindakan ini juga sebagai bentuk kontrol terhadap pejabat negara dengan kewenangannya.

Sebelum disetujui dan disahkan menjadi undang-undang oleh DPR, Perppu tidak boleh diuji oleh Mahkamah Konstitusi. Namun beda halnya jika dalam hal ini Perppu tersebut dibuat dengan iktikad buruk dan dapat menimbulkan ketidak adilan sebagai akibat dari berlakunya Perppu tersebut.

Bahkan bisa saja terjadi sebelum Perppu itu di setujui atau tidak di setujui oleh DPR, akibat dari Perppu tersebut sudah tercapai tanpa bisa dikoreksi lagi, kekhawatiran muncul sebab Perppu ini dibuat secara sepihak oleh presiden dan DPR bisa jadi tidak dapat bersidang karena sengaja dihambat oleh kekuatan politik tertentu.

Dalam kasus semacam ini, apakah korban dari hilangnya hak atau kewenangannya akibat dari berlakunya Perppu, mengajukan permohonan ke Mahkamah Konstitusi, lalu Mahkamah Konstitusi harus menunggu terlebih dahulu Perppu tersebut disahkan dan berganti status menjadi undang-undang lalu boleh diajukan ke Mahkamah Konstitusi. Apabila hendak melalui proses normal yakni pengujian oleh DPR (political review) tentu akan membutuhkan proses yang lama pula.

Belum lagi jika Presiden selaku pembuat Perppu memperlambat mengajukan RUU penetapan Perppu tersebut ke DPR. Sehingga atas berlakunya Perppu tersebut yang entah akan sampai kapan waktu berlakunya tergantung jadwal sidang DPR maka akan dapat menimbulkan kerugian konstitusional yang serius, sudah selayaknya memang perlu ada aturan hukum yang mengatur batas waktu pembahasan suatu Perppu oleh DPR untuk menerima atau menolaknya sejak diterbitkan oleh Presiden dan segala akibat hukumnya.

Hal ini bermaksud untuk melaksanakan kewenangan political review yang dimiliki oleh DPR dan untuk menjamin kepastian hukum seperti yang telah diamanatkan oleh UUD 1945. Dalam kondisi seperti ini Mahkamah Konstitusi cukup beralasan untuk memeriksa dan menguji Perppu, dan jika terbukti melanggar UUD 1945, maka bisa saja demi keadilan dengan mendahului DPR, Perppu itu dinyatakan bertentangan dengan UUD 1945 dan tidak mempunyai kekuatan hukum mengikat. Berdasarkan hal-hal tersebut maka Perppu dapat diuji oleh Mahkamah Konstitusi melalui penekanan pada 
penafsiran sosiologis dan teleologis, dalam hal ini peraturan perundangundangan disesuaikan dengan hubungan dan situasi sosial.

Mahkamah Konstitusi berfungsi dalam penegakan konstitusi untuk mewujudkan negara hukum yang demokrasi, Negara hukum yang demokrasi adalah negara yang menolak melepaskan kekuasaan tanpa pengawasan. Negara yang pola hidupnya berdasarkan hukum yang adil dan demokratis, penegakan konstitusi yang benar adalah penegakan konstitusi yang memberikan perlindungan dan maanfaat bagi setiap warga negara dalam rangka tegaknya supremasi konstitusi sebagai hukum dasar tertinggi negara. ${ }^{16}$

Lalu problem yang akan di timbulkan dari Pengujian Perppu yang dilakukan oleh Mahkamah Konstitusi berakibat pada kewenangan legislative review DPR terhadap Perppu, karena dalam perkara pengujian UU, putusan Mahkamah Konstitusi bersifat erga omnes yang berarti mengikat dan harus dipatuhi oleh seluruh warga negara, yang berakibat hukum bukan hanya kepada para pihak yang berkepentingan saja, melainkan juga kepada seluruh pejabat publik dan seluruh komponen masyarakat tidak terkecuali pula DPR. Putusan Mahkamah Konstitusi juga

\footnotetext{
${ }^{16}$ Abdul Latif, Op, cit., hlm. 103.
}

bersifat final dan mengikat dan langsung memperoleh kekuatan hukum tetap (in kracht van gawijsde) sejak putusan dibacakan.

\section{Putusan Mahkamah Konstitusi} yang dibacakan dalam sidang terbuka untuk umum akan langsung menjadi sumber hukum tata negara (sources of constitutional law) yang berarti mengikat seluruh lembaga negara, tidak terkecuali DPR. Jika permohonan pengujian Perppu dikabulkan judiicial review-nya, berarti sudah menghilangkan hak konstitusi DPR untuk melakukan political review di karenakan putusan Mahkamah Konstitusi adalah bersifat Final dan mengikat maka ini akan menimbulkan sengketa kewenangan antara Mahkamah Konstitusi Dan DPR. Namun demekian Mahkamah Konstitusi mendalilkan keberwenangannya dalam putusannya bahwa Perppu melahirkan norma hukum dan sebagai norma hukum baru akan dapat menimbulkan, status hukum baru, hubungan hukum baru, dan akibat hukum baru. Norma hukum tersebut lahir sejak Perppu disahkan dan nasib dari norma hukum tersebut tergantung kepada persetujuan DPR untuk menerima atau menolak norma hukum Perppu, namun demikian sebelum adanya pendapat DPR untuk menolak atau menyetujui Perppu, norma hukum 
tersebut adalah sah dan berlaku seperti Undang-Undang. Oleh karena itu dapat menimbulkan norma hukum yang kekuatan mengikatnya sama dengan Undang-Undang maka terhadap norma yang terdapat dalam Perppu tersebut Mahkamah Konstitusi dapat menguji apakah bertentangan secara materiil dengan UUD 1945. Dengan demikian Mahkamah Konstitusi berwenang untuk menguji Perppu terhadap UUD 1945.

\section{Penutup}

Dasar kewenangan Mahkamah Konstitusi dalam memutus perkara pengujian Perppu terhadap UUD 1945 adalah Putusan Nomor 138/PUU-VII/2009 tentang Pengujian Peraturan Pemerintah Pengganti UndangUndang Nomor 4 Tahun 2009 tentang Perubahan Atas Undang-Undang Nomor 30 Tahun 2002 tentang Komisi Pemberantasan Tindak Pidana Korupsi terhadap UndangUndang Dasar Negara Republik Indonesia Tahun 1945. Putusan a quo sebagai yurisprudensi kewenangan Mahkamah Konstitusi dalam menguji Perppu dengan pertimbangan bahwa norma hukum yang terkandung dalam Perppu kekuatan mengikatnya sama dengan Undang-Undang, maka terhadap norma yang terdapat dalam Perppu tersebut Mahkamah Konstitusi dapat menguji apakah bertentangan secara materiil dengan UUD 1945.

Penafsiran yang digunakan oleh hakim konstitusi untuk menguji Perppu adalah interpretasi teleologis dan sosiologis. Interpretasi teleologis atau sosiologis ditetapkan berdasarkan tujuan kemasyarakatan. Karena kebutuhan masyarakat yang terus berkembang sehingga penambahan kewenangan yang dimiliki oleh Mahkamah Konstitusi untuk menguji Perppu melalui putusannya (yurisprudensi) sebagai sumber hukum.

\section{Pustaka Acuan}

Ali, Zainuddin. Metode Penelitian Hukum. Jakarta: Sinar Grafika, 2016.

Asshiddiqie, Jimly. Hukum Acara Pengujian Undang-Undang. [Cet. 2.]. Jakarta: Sekretariat Jenderal dan Kepaniteraan Mahkamah Konstitusi RI, 2006.

Perihal Undang-Undang Di Indonesia. Jakarta: Mahkamah Konstitusi RI Sekretariat Jenderal dan Kenpaniteraan, 2006.

Chandranegara, Ibnu Sina. "Perbandingan Fungsi Dan Kedudukan Mahkamah Konstitusi Dan Lembaga Sejenisnya Di Tiga Negara (Indonesia, Austria Dan Perancis)." Socio Justisia 1, no. 1 (March 17, 2018). Accessed April 27,2019.https://jurnal.umj.ac.id/index .php/socio/article/view/2534.

Eddyono, Luthfi Widagdo. "Penyelesaian Sengketa Kewenangan Lembaga Negara Oleh Mahkamah Konstitusi." 
Jurnal Konstitusi 7, no. 3 (2010): 148.

Fajar ND, Mukti, Yulianto Achmad, and Dualisme penelitian hukum : normatif dan empiris. Dualisme penelitian hukum: normatif \& empiris. Yogyakarta: Pustaka Pelajar, 2010.

Ghoffar, Abdul. "Mewujudkan Mahkamah Konstitusi Sebagai Peradilan Yang Akuntabel Dan Terpercaya." Pandecta: Research Law Journal 13, no. 2 (December 31, 2018): 76-88.

Kristian. Kewenangan Mahkamah Konstitusi Terhadap Constitutional Complaint. Pt. Animage. Jakarta, 2019.

Latief, Abdul. Fungsi Mahkamah Konstitusi dalam upaya mewujudkan negara hukum demokrasi. Yogyakarta: Kreasi Total Media, 2007.

Lowi, Theodore J., Benjamin Ginsberg, Kenneth A. Shepsle, and Stephen Ansolabehere. American Government: Power and Purpose. W.W. Norton, 2015.

Ramdan, Ajie. "Kewenangan Penuntut Umum Mengajukan Peninjauan Kembali Pasca Putusan Mahkamah Konstitusi No. 33/PUU-XIV/2016.” Jurnal Ilmiah Kebijakan Hukum 11, no. 2 (July 25, 2017): 181-192.
Rohim, Nur. "Kontroversi Pembentukan Perppu Nomor 1 Tahun 2013 Tentang Mahkamah Konstitusi Dalam Ranah Kegentingan Yang Memaksa.” Jurnal Cita Hukum 2, no. 1 (2014).

Rusli, Hardijan. "Metode Penelitian Hukum Normatif: Bagaimana?” (2006).

Siahaan, Maruarar, and Indonesia. Hukum acara Mahkamah Konstitusi Republik Indonesia. Jakarta: Sinar Grafika, 2011.

Sunggono, Bambang. Metodologi penelitian hukum, 2007.

Tutik, Titik Triwulan. Konstruksi hukum tata negara Indonesia pasca-amandemen UUD 1945. Jakarta: Kencana, 2010. 